\section{Uvodna beseda}

Revija Slovenski jezik - Slovene Linguistic Studies bo periodično jezikoslovno literaturo bogatila vsako drugo leto. Od svoje imenske vzornice, revije Slovenski jezik, ki je v letih 1938 do 1941 izhajala $v$ Ljubljani, in od drugih slovenističnih revij se razlikuje predvsem $\mathrm{v}$ tem, da je samo jezikoslovna, od druge jezikoslovne periodike pa $\mathrm{v}$ tem, da prinaša le slovenistične prispevke. Prostor in $\mathrm{s}$ tem raison d'être pričujoče revije je torej $\mathrm{v}$ matematičnem preseku množic jezikoslovje in slovenistika. Njen drugi razpoznavni znak sta večjezičnost in mednarodni značaj, lastnosti, s katerima bi radi spodbudili dialog o predmetu, ki presega državne in jezikovne meje. $\mathrm{Z}$ izdajanjem take revije želimo prispevati $\mathrm{k}$ nastajanju kakovostnih slovenističnih jezikoslovnih raziskav, obogatenih $\mathrm{z}$ idejami in dognanji raziskovalcev različnih strokovnih usmeritev, izobrazbe in kulturnih pogledov. Drugi razlogi, ki so privedli k oživitvi revije, so samo za nameček: avtorjem obljubljamo kar se da široko svobodo, in to tako $\mathrm{v}$ izbiri tematike kakor tudi $\mathrm{v}$ izboru jezi$\mathrm{ka}$ in sloga pisanja, uporabi posebnih znakov, grafičnih prikazov in podobnega. Pri izboru za objavo štejeta le kakovost in ustreznost prispevkov, ki ju vzajemno anonimno za vsak primer posebej presojajo izbrani recenzenti.

V imenu celotnega uredniškega odbora bi se rada zahvalila vsem, ki so omogočili izid prve številke: avtorjem, ki so nam zaupali svoja dela, recenzentom, ki so jih pregledali in po potrebi predlagali spremembe ali dopolnila, in ne nazadnje izdajateljema, Znanstvenoraziskovalnemu centru Slovenske akademije

\section{From the Editors}

The biennial Slovenski jezik Slovene Linguistic Studies differs from other Slovenistic periodicals, including its namesake Slovenski jezik (which appeared from 1938 to 1941 in Ljubljana), in that it is devoted exclusively to linguistics; it differs from linguistic periodicals in that it is devoted exclusively to research on Slovene. Its place and thus raison d'etre is found at the intersection of linguistics and the Slovene language. Its further distinctive features are its multilingual and international character, which are aimed at fostering a dialogue on the subject that transcends the borders of states and languages. We hope that with the publication of this journal we will thus encourage the production of high-quality research in the field of Slovene linguistics, enriched by the ideas and discoveries of linguists of various kinds of training, schools of thought, and cultural viewpoints. Other motivations for initiating the journal are incidental: we intend to give authors as much freedom as possible in choosing their topics, language of explication, as well as in matters of style, use of special characters, graphics, etc. The only conditions for publication are the quality and appropriateness of topic, which are judged by independent referees using the double-blind system.

On behalf of the Editorial Board we wish to thank those who have made possible the publication of the first issue: the authors, who entrusted their work to us; the referees, who reviewed the contributions and gave suggestions for changes and amendments; and last, but not least, the publishers, The Scientific Research Center of the Slovene 
znanosti in umetnosti in Centru za humanistiko Joyce in Elizabeth Hall Univerze v Kansasu, ki sta gmotno podprla oživitev revije. Dodatna sredstva za dejavnost $\mathrm{v}$ ZDA je prispeval tudi Center za ruske in vzhodnoevropske študije Univerze v Kansasu.

Vsem omenjenim se zahvaljujeva tudi za potrpljenje in razumevanje, ki so ga izkazali zaradi zamude pri izdaji prve številke. Pričakujeva, da nam bodo izkušnje, ki smo si jih pridobili z uredniškim delom, omogočile, da bodo naslednji letniki izhajali $\mathrm{v}$ predvidenih rokih.

Marko Snoj in/and Marc L. Greenberg
Academy of Arts and Sciences and The Joyce and Elizabeth Hall Center for the Humanities at the University of Kansas, who gave financial support for the production of the journal. Additional funding for U.S. operations was provided by the Center for Russian and East European Studies, University of Kansas.

We wish to thank all those mentioned above for their patience and understanding in light of the delays that attended the publication of the first issue. We expect that with the benefit of experience gained in the preparation of this issue the next one will run on schedule. 